\title{
Seasonal variation of groundwater quality in a part of Vadodara District for irrigation, Gujarat, India
}

\author{
S.M. Shah ${ }^{1}$, N. J. Mistry ${ }^{2}$ \\ 1 Research Scholar, Sardar Vallabhbhai National Institute of Technology, (SVNIT), Surat 395 007, Gujarat, \\ INDIA \\ 2 Civil Engineering Department, Sardar Vallabhbhai National Institute of Technology (SVNIT), Surat 395007 , \\ Gujarat, INDIA
}

\begin{abstract}
The area in Vadodara district, Gujarat, India, is selected to discuss the impact of seasonal variation of groundwater quality on irrigation, where the agriculture is the main livelihood of rural people and the groundwater is the main source for irrigation and drinking. Groundwater samples collected seasonally, pre and post-monsoons, during three years from Twenty five wells in the area were analyzed for $p H, E C, T D S$, TH, $\mathrm{Ca}^{2+}, \mathrm{Mg}^{2+}, \mathrm{Na}^{+}, \mathrm{K}^{+}, \mathrm{CO}_{3}{ }^{2-}, \mathrm{HCO}_{3}{ }^{-}, \mathrm{Cl}^{-}, \mathrm{SO}_{4}{ }^{2-}, \mathrm{NO}_{3}{ }^{-}$and $\mathrm{F}^{-}$. Various tools such as Electrical conductivity (EC), Sodium Absorption Ratio (SAR), United States Salinity Laboratory (USSL) were used to evaluate the quality of water and its suitability for irrigation purposes. Results of SAR shows that many of the wells during premonsoon illustrate high values indicating the unsuitable nature of groundwater for irrigation but during post monsoon, SAR values found to be decreased due to the dilution effect of precipitation by monsoon.
\end{abstract}

Key words: agricultural activity, Groundwater pollution, irrigation water quality, sodium adsorption ratio (SAR), USSL.

\section{Introduction}

Salinity problem is generally most pronounced in arid and semi arid regions. The increased demand for water due to agriculture expansion, growing population and urbanization, ground water resources are depleting day by day leads to increase in the salinity of water [1]. This problem is often characterised by high salt content in the root inhabited layers. Some of these salts adversely affect the growth of crops and may considerably reduce the final produce. The application of water with a sodium imbalance can further reduce yield under certain soil texture conditions. Reductions in water infiltration can occur when irrigation water contains high sodium relative to the calcium and magnesium contents. The most common measure to assess sodicity in water and soil is called the Sodium Adsorption Ratio (SAR) [2,3].

The increased knowledge of geochemical evolution of water quality could lead to effective management of water resources. In India and various parts of the world, numerous studies have been carried out to assess the geochemical characteristics of groundwater.( M. Amir Khattak 2012, Li Peiyue 2010, R. K. Tatawat, 2007 , Izhar-ul-Haq 2007,Rajdeep Kaur 2011; Chitradevi S. 2010, Abhay kumar singh 2011,Saumitra Mukherjee 2005)

\section{Study Area}

It has the area of $148.95 \mathrm{~km}^{2}$ and a population of 4.1 million according to the $2010-11$ censuses. The city sites on the banks of the River Vishwamitri, in central Gujarat. Vadodara is the third most populated city in the Indian, State of Gujarat after Ahmadabad and Surat. The city has Nandesari Industrial Estate which is comprised of around 1,200 small and large- scale industries i.e. dye industries, engineering, textile, and Pharmaceutical and petroleum industries.

Study Area: Taluka: Padra, Dabhoi and Savli, Vadodara, Waghodiya.

\section{GEOLOGY AND HYDROGEOLOGY}

The study of geo hydrological condition is very important as far as the exploration and recharge of the ground water is concerned. The study needs special attention to the city like Vadodara which is highly complicated. Some of the areas are having good aquifers which are good for exploration and recharge, but some of the areas are having non productive saline aquifers which are not good for exploration as well as recharge. Geohydrology it is recent to sub recent alluvium formation (comprises of alluvium Sand, clay, silt, gravel etc.) with alternate clay, sand, silt gravel etc. 


\section{Material And Methods}

The current study was designed to investigate the conditions of groundwater contamination in the study area. The hydro geochemistry study was undertaken by randomly collected twenty five groundwater samples from dug and tube wells.

Samples from open well for confined aquifer of the study area during May (Pre Monsoon) and October (Post Monsoon) for years 2009 and 2010, 2011 were drawn and analyzed as per the Indian standards. The hydrological study was undertaken by groundwater samples for different parameters shown in the Table I and Table II.

Water quantity parameters such as $\mathrm{pH}$, electrical conductivity (EC), Total dissolved solids (TDS), Total hardness $(\mathrm{TH}), \mathrm{CO}_{3}{ }^{-}, \mathrm{HCO}_{3}{ }^{-}$, Calcium $\left(\mathrm{Ca}^{+2}\right)$, Magnesium $\left(\mathrm{Mg}^{+2}\right)$, Chloride $\left(\mathrm{Cl}^{-}\right)$, Sodium $\left(\mathrm{Na}^{+}\right)$and Potassium $\left(\mathrm{K}^{+}\right)$were estimated by standard method[4].

\subsection{Quality of irrigation water}

Good irrigation water is the one which will not retard the plant growth. The quality of irrigation water depends upon various types of impurities present in water, the following being the prominent ones:

1. Concentration of sediments in water

2. Total Concentration of soluble salts (known as TDS)

3. Proportion of Sodium ions to other cations

4. Concentration of toxic elements such as boron Concentration

5. Concentration of bicarbonate in relation to the concentration of calcium and magnesium

6. Bacterial concentration

Besides the factors already discussed, many additional factors affect water suitability for irrigation. In this radical we limit ourselves to salinity and sodium hazards associated with water use for irrigation. High concentration of salts in water may be harmful in the long run. Similarly, if the water contains high concentration of Sodium ions, the irrigation soils become plastic and sticky when wet and become prone to form clods and they crust on dying. Due to interaction between different water qualities parameters, in order to classification of water quality should be considered combinations of theses parameters [5].

\subsection{USSL Diagram for Irrigation Water Quality Evaluation}

A more detailed analysis, however, with respect to the irrigation suitability of the groundwater, was made by plotting the data as shown in Fig.1 (SAR and salinity hazard) according to the diagram of the US Salinity Laboratory of the Department of Agriculture (US Salinity Laboratory Staff, 1954).The USSL diagram best explains the combined effect of Sodium hazard and salinity hazard [6,7].

The Fig.1 shows a simple scatter chart of sodium hazard (SAR) on the Y-axis verses salinity hazard (EC) on the X-axis. The EC is platted by default in a log scale. Water can be grouped into 16 classes. Waters are divided into four classes with respect to conductivity, the dividing points between classes being at 250,750 and 2250 micromohs per centimetre. These classes limits were selected in accordance with the relationship between the electrical conductivity of irrigation waters and electrical conductivity of saturation extracts of soil.

The curves of Fig. 1 can be constructed by the use of the following empirical equations (US Salinity Laboratory Staff, 1954):

$$
\begin{aligned}
& \text { Upper curve: } S=43.75-8.87(\log C) \\
& \text { Middle curve: } S=31.31-6.66(\log C) \\
& \text { Lower curve: } S=18.87-4.44(\log C)
\end{aligned}
$$

Where, S, C and Log are abbreviation of Sodium Adsorption Ratio (SAR), Electrical Conductivity (EC), in micromohs per centimetre and logarithm to base 10, respectively. These equations plot as straight lines on rectangular coordinate paper $\log \mathrm{C}$ is used. Using the SAR and the $\mathrm{EC}$ value as coordinates, locate the corresponding point on the diagram. Position of the point determines the quality classification of the water. The significance and interpretation of the quality class rating on the diagram are summarized as:

Based on the EC, irrigation water can be classified into four categories,

Low- salinity water $\left(\mathrm{C}_{1}\right)$ can be used for irrigation with most crops on most soils with little likelihood that soil salinity will develop. Some leaching is required, but this occurs under normal irrigation practices except in soils of extremely low permeability.

Medium- salinity water $\left(\mathrm{C}_{2}\right)$ can be used if a moderate amount of leaching occurs. Plant with moderate salt-tolerance can be grown in most cases without special practices for salinity control.

High- salinity water $\left(\mathrm{C}_{3}\right)$ cannot be used on soils with restricted drainage. Even with adequate drainage, special management for salinity control may be required and plants with good salt tolerance should be selected. 
Very high salinity water $\left(\mathrm{C}_{4}\right)$ is not suitable for irrigation under ordinary conditions, but may be used occasionally under very special circumstances. The soil must be permeable, drainage must be adequate, and irrigation water must be applied in excess to provide considerable leaching and very salt tolerance crop should be selected.

The sodium adsorption ratio (SAR) is commonly used as an index for evaluating the sodium hazard associated with an irrigation water supply. The formula derived by Suarez (1981) is generally recognized as the most applicable technique for determining the adjusted SAR hazard index $[8,9,10]$.

$$
S A R=\frac{\mathrm{Na}^{+}}{\sqrt{\mathrm{Ca}^{+2}}+\mathrm{Mg}^{+2} / 2}
$$

Where, cation measurements are expressed in milliequivalents per liter (meq/l).

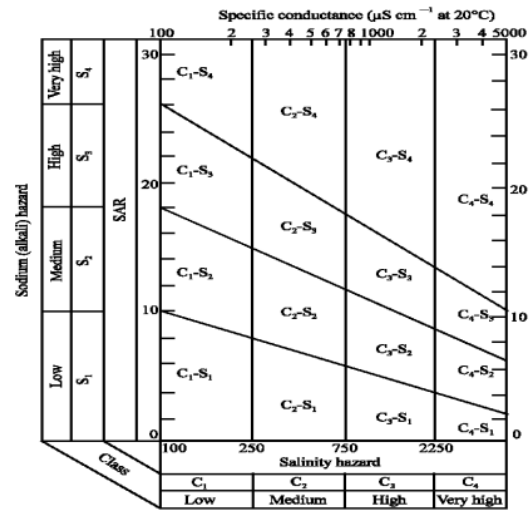

Figure: 1 USSL diagram for classification of irrigation waters (US Salinity Laboratory Staff, 1954)

Table: 1 Classification of groundwater on the basis of SAR

\begin{tabular}{|c|c|c|}
\hline Parameter & Range & Water Class \\
\hline \multirow{4}{*}{ SAR } & $<10$ & Excellent \\
\cline { 2 - 3 } & $10-18$ & Good \\
\cline { 2 - 3 } & $18-26$ & Doubtful \\
\cline { 2 - 3 } & $>26$ & Unsuitable \\
\hline
\end{tabular}

\section{Result And Discussion}

The measured value of EC is varied from 270 to $8940 \mu \mathrm{S} / \mathrm{cm}$ and the computed value of SAR is between 0.65 and 30.84 for pre monsoon (Table 1) and for the post monsoon the measured value of EC is varied from 420 to $5690 \mu \mathrm{S} / \mathrm{cm}$ and the computed value of SAR is between 0.70 and 45.23 of the groundwater collected from the study area. The chemical data of the area plotted in the salinity hazard versus sodium hazard diagram designed by the USSL 1954, Fig.1 which judges the water quality for irrigation.

The values of electrical conductivity and SAR values, plotted on a US Salinity diagram (Fig.1), show that in the zone of C2-S1 and C3-S1, indicating high-salinity hazard (C3) Medium-salinity hazard (C2), and low-sodium hazard (S1) $52 \%$ of the total groundwater samples $(2,4,5,6,8,9,12,14,15,16,17,18,21,23,25)$ fall for pre monsoon and $40 \%$ of the total groundwater samples $(2,4,5,6,8,9,12,14,15,16,17,18,21,23,25)$ fall for post monsoon which can be used for irrigation on almost all soil types, with little danger of exchangeable sodium.

Table: 2 Water samples quality results using USSL diagram for 25 wells in the study area (Pre Monsoon)

\begin{tabular}{|c|c|c|c|c|c|c|c|c|c|}
\hline $\begin{array}{c}\text { Well } \\
\text { No. }\end{array}$ & \multicolumn{5}{|c|}{$\mathbf{2 0 0 9}$} & \multicolumn{5}{|c|}{$\mathbf{2 0 1 0}$} & \multicolumn{2}{|c|}{$\mathbf{2 0 1 1}$} \\
\hline & EC & SAR & Class & EC & SAR & Class & EC & SAR & Class \\
\hline 1 & 4030 & 15.09 & C4-S2 & 3640 & 15.72 & C4-S2 & 2740 & 11.88 & C4-S2 \\
\hline 2 & 830 & 5.40 & C3-S1 & 1680 & 14.37 & C3-S2 & 600 & 3.74 & C2-S1 \\
\hline 3 & 2310 & 9.99 & C4-S1 & 2360 & 10.56 & C4-S2 & 1650 & 8.19 & C3-S1 \\
\hline 4 & 450 & 1.20 & C2-S1 & 550 & 2.37 & C2-S1 & 470 & 1.96 & C2-S1 \\
\hline 5 & 1060 & 8.53 & C3-S1 & 1390 & 10.58 & C3-S2 & 1130 & 9.36 & C3-S1 \\
\hline 6 & 610 & 1.49 & C2-S1 & 500 & 3.94 & C2-S1 & 990 & 6.57 & C3-S1 \\
\hline 7 & 910 & 1.58 & C3-S1 & 890 & 2.01 & C3-S1 & 1250 & 3.12 & C3-S1 \\
\hline 8 & 490 & 0.80 & C2-S1 & 950 & 2.08 & C3-S1 & 680 & 1.37 & C2-S1 \\
\hline
\end{tabular}


Seasonal variation of groundwater quality in a part of Vadodara District for irrigation, Gujarat,

\begin{tabular}{|c|c|c|c|c|c|c|c|c|c|}
\hline 9 & 990 & 6.08 & $\mathrm{C} 3-\mathrm{S} 1$ & 1280 & 7.36 & $\mathrm{C} 3-\mathrm{S} 1$ & 1380 & 13.96 & $\mathrm{C} 3-\mathrm{S} 2$ \\
\hline 10 & 2870 & 9.61 & $\mathrm{C} 4-\mathrm{S} 1$ & 2420 & 5.55 & $\mathrm{C} 4-\mathrm{S} 1$ & 2000 & 5.70 & C3-S1 \\
\hline 11 & 2660 & 4.03 & $\mathrm{C} 4-\mathrm{S} 1$ & 2060 & 2.61 & C3-S1 & 2410 & 3.56 & C4-S1 \\
\hline 12 & 500 & 0.65 & $\mathrm{C} 2-\mathrm{S} 1$ & 550 & 0.78 & $\mathrm{C} 2-\mathrm{S} 1$ & 270 & 0.65 & $\mathrm{C} 2-\mathrm{S} 1$ \\
\hline 13 & 1380 & 5.54 & C3-S1 & 1260 & 8.36 & C3-S1 & 1490 & 15.37 & C3-S2 \\
\hline 14 & 1550 & 4.99 & $\mathrm{C} 3-\mathrm{S} 1$ & 1370 & 2.77 & C3-S1 & 1170 & 4.34 & C3-S1 \\
\hline 15 & 1600 & 3.16 & C3-S1 & 2120 & 2.40 & C3-S1 & 930 & 1.76 & $\mathrm{C} 3-\mathrm{S} 1$ \\
\hline 16 & 1140 & 3.53 & $\mathrm{C} 3-\mathrm{S} 1$ & 1040 & 2.51 & C3-S1 & 920 & 3.67 & C3-S1 \\
\hline 17 & 1690 & 1.95 & $\mathrm{C} 3-\mathrm{S} 1$ & 8940 & 7.16 & $\mathrm{C} 4-\mathrm{S} 1$ & 3640 & 19.19 & C4-S1 \\
\hline 18 & 840 & 4.39 & C3-S1 & 660 & 0.91 & $\mathrm{C} 2-\mathrm{S} 1$ & 560 & 2.35 & $\mathrm{C} 2-\mathrm{S} 1$ \\
\hline 19 & 2960 & 9.49 & $\mathrm{C} 4-\mathrm{S} 1$ & 3320 & 5.78 & $\mathrm{C} 4-\mathrm{S} 1$ & 2780 & 7.33 & C4-S1 \\
\hline 20 & 1400 & 13.05 & C3-S2 & 1470 & 11.64 & $\mathrm{C} 3-\mathrm{S} 2$ & 1350 & 9.68 & C3-S1 \\
\hline 21 & 740 & 2.65 & $\mathrm{C} 2-\mathrm{S} 1$ & 740 & 1.86 & $\mathrm{C} 2-\mathrm{S} 1$ & 610 & 2.46 & $\mathrm{C} 2-\mathrm{S} 1$ \\
\hline 22 & 2310 & 15.64 & $\mathrm{C} 4-\mathrm{S} 2$ & 2220 & 11.71 & $\mathrm{C} 4-\mathrm{S} 2$ & 1680 & 12.60 & $\mathrm{C} 3-\mathrm{S} 2$ \\
\hline 23 & 780 & 5.80 & $\mathrm{C} 3-\mathrm{S} 1$ & 860 & 6.51 & C3-S1 & 670 & 7.91 & $\mathrm{C} 2-\mathrm{S} 1$ \\
\hline 24 & 6320 & 30.84 & $\mathrm{C} 4-\mathrm{S} 4$ & 5750 & 32.31 & $\mathrm{C} 4-\mathrm{S} 4$ & 4240 & 30.79 & C4-S4 \\
\hline 25 & 1340 & 7.50 & $\mathrm{C} 3-\mathrm{S} 1$ & 1360 & 7.38 & C3-S1 & 1120 & 6.39 & C3-S1 \\
\hline
\end{tabular}

The zone of C4-S4, C4-S3, C4-S2, C4-S1 indicating poor quality of water for irrigating plants. $20 \%$ of pre monsoon groundwater samples $(1,3,11,19,24)$ and $32 \%$ of post monsoon groundwater samples $(1,3,10,11,17,19,22,24)$ are following in this category.

The zone of C3-S1, C4-S1, C3-S2, C3-S3 indicating poor quality of water for irrigating plants. $16 \%$ of pre monsoon groundwater samples $(7,10,13,20,22)$ and $16 \%$ of post monsoon groundwater samples $(2,5,7,9)$ are following in this category. This shows variation in the salinity hazards and sodium hazards from low to very high for the study periods for year 2009 to 2011.

In the zone of medium salinity hazard C2 and low sodium hazard S1, only $12 \%$ of the groundwater samples are observed its good quality for irrigation for pre monsoon and post monsoon season for all three years 2009-2011.

Table: 3 Water samples quality results using USSL diagram for 25 wells in the study area (Post Monsoon)

\begin{tabular}{|c|c|c|c|c|c|c|c|c|c|}
\hline & \multicolumn{3}{|c|}{2009} & \multicolumn{3}{|c|}{2010} & \multicolumn{3}{|c|}{2011} \\
\hline $\begin{array}{l}\text { Well } \\
\text { No. }\end{array}$ & EC & SAR & Class & EC & SAR & Class & EC & SAR & Class \\
\hline 1 & 1620 & 10.06 & $\mathrm{C} 3-\mathrm{S} 2$ & 3860 & 20.32 & $\mathrm{C} 4-\mathrm{S} 3$ & 4460 & 21.80 & $\mathrm{C} 4-\mathrm{S} 3$ \\
\hline 2 & 1200 & 8.83 & $\mathrm{C} 3-\mathrm{S} 1$ & 730 & 5.09 & $\mathrm{C} 2-\mathrm{S} 1$ & 630 & 3.25 & $\mathrm{C} 2-\mathrm{S} 1$ \\
\hline 3 & 2410 & 9.37 & $\mathrm{C} 4-\mathrm{S} 1$ & 2200 & 6.83 & $\mathrm{C} 3-\mathrm{S} 1$ & 2300 & 10.58 & $\mathrm{C} 4-\mathrm{S} 2$ \\
\hline 4 & 580 & 3.23 & $\mathrm{C} 2-\mathrm{S} 1$ & 990 & 2.00 & $\mathrm{C} 3-\mathrm{S} 1$ & 650 & 2.21 & $\mathrm{C} 2-\mathrm{S} 2$ \\
\hline 5 & 1200 & 8.54 & $\mathrm{C} 3-\mathrm{S} 1$ & 1360 & 9.49 & $\mathrm{C} 3-\mathrm{S} 1$ & 1520 & 11.73 & C3-S2 \\
\hline 6 & 810 & 0.71 & $\mathrm{C} 3-\mathrm{S} 1$ & 950 & 1.15 & $\mathrm{C} 3-\mathrm{S} 1$ & 740 & 2.13 & $\mathrm{C} 2-\mathrm{S} 1$ \\
\hline 7 & 1090 & 4.32 & $\mathrm{C} 3-\mathrm{S} 1$ & 1440 & 1.17 & $\mathrm{C} 3-\mathrm{S} 1$ & 2660 & 8.06 & C4-S1 \\
\hline 8 & 790 & 0.75 & $\mathrm{C} 3-\mathrm{S} 1$ & 510 & 0.89 & $\mathrm{C} 2-\mathrm{S} 1$ & 1290 & 1.22 & C3-S1 \\
\hline 9 & 1750 & 3.35 & $\mathrm{C} 3-\mathrm{S} 1$ & 1330 & 10.35 & $\mathrm{C} 3-\mathrm{S} 1$ & 1370 & 8.41 & $\mathrm{C} 3-\mathrm{S} 1$ \\
\hline 10 & 1330 & 5.29 & $\mathrm{C} 3-\mathrm{S} 1$ & 1930 & 8.61 & $\mathrm{C} 3-\mathrm{S} 1$ & 2430 & 7.03 & C4-S1 \\
\hline 11 & 2760 & 8.20 & $\mathrm{C} 4-\mathrm{S} 1$ & 700 & 1.70 & $\mathrm{C} 2-\mathrm{S} 1$ & 3200 & 8.59 & C4-S1 \\
\hline 12 & 480 & 0.73 & $\mathrm{C} 2-\mathrm{S} 1$ & 640 & 0.96 & $\mathrm{C} 2-\mathrm{S} 1$ & 540 & 0.87 & $\mathrm{C} 2-\mathrm{S} 1$ \\
\hline 13 & 1660 & 5.36 & $\mathrm{C} 3-\mathrm{S} 1$ & 3860 & 8.01 & $\mathrm{C} 4-\mathrm{S} 1$ & 1590 & 8.89 & C3-S1 \\
\hline 14 & 1340 & 4.44 & $\mathrm{C} 3-\mathrm{S} 1$ & 1210 & 3.70 & $\mathrm{C} 3-\mathrm{S} 1$ & 1230 & 1.87 & $\mathrm{C} 3-\mathrm{S} 1$ \\
\hline 15 & 1920 & 2.93 & $\mathrm{C} 3-\mathrm{S} 1$ & 1180 & 2.16 & $\mathrm{C} 3-\mathrm{S} 1$ & 870 & 1.62 & $\mathrm{C} 3-\mathrm{S} 1$ \\
\hline 16 & 1170 & 4.23 & C3-S1 & 3300 & 7.82 & C4-S1 & 940 & 3.06 & C3-S1 \\
\hline 17 & 810 & 1.56 & $\mathrm{C} 3-\mathrm{S} 1$ & 320 & 0.70 & $\mathrm{C} 2-\mathrm{S} 1$ & 420 & 1.08 & $\mathrm{C} 2-\mathrm{S} 1$ \\
\hline 18 & 490 & 0.9 & $\mathrm{C} 2-\mathrm{S} 1$ & 500 & 1.33 & $\mathrm{C} 2-\mathrm{S} 1$ & 440 & 1.05 & $\mathrm{C} 2-\mathrm{S} 1$ \\
\hline 19 & 3310 & 14.36 & C4-S2 & 2710 & 7.25 & C4-S1 & 2780 & 8.69 & C4-S1 \\
\hline
\end{tabular}


Seasonal variation of groundwater quality in a part of Vadodara District for irrigation, Gujarat,

\begin{tabular}{|c|c|c|c|c|c|c|c|c|c|}
\hline 20 & 1430 & 7.70 & C3-S1 & 1460 & 8.82 & C3-S1 & 1700 & 16.11 & C3-S2 \\
\hline 21 & 740 & 2.19 & C2-S1 & 690 & 3.13 & C2-S1 & 710 & 1.49 & C2-S1 \\
\hline 22 & 2210 & 13.46 & C3-S2 & 2330 & 8.53 & C3-S1 & 2030 & 21.53 & C3-S3 \\
\hline 23 & 790 & 3.28 & C3-S1 & 760 & 7.89 & C3-S1 & 810 & 8.61 & C3-S1 \\
\hline 24 & 5690 & 25.66 & C4-S4 & 5590 & 43.35 & C4-S4 & 7810 & 45.23 & C4-S4 \\
\hline 25 & 1320 & 3.11 & C3-S1 & 1370 & 6.16 & C3-S1 & 1350 & 6.91 & C3-S1 \\
\hline
\end{tabular}

\section{Conclusion}

The groundwater sources in around Vadodara district of Gujarat have been evaluated for their chemical composition and suitability for irrigation purposes. In the study area majority of groundwater samples are within permissible limits prescribed for irrigation water.US Laboratory Salinity Staff diagrams reveal that approximately $60 \%$ of groundwater samples from pre monsoon and $50 \%$ of groundwater samples from post monsoon locations are suitable for irrigation purposes with little danger of exchangeable Sodium. Only $12 \%$ samples for pre and post monsoon are good for irrigation for the study period 2009-2011 of the Vadodara district.

\section{Acknowledgment}

The authors express gratitude to the Gujarat ground water resource department for their support while procuring the data of the study area.

\section{Journal Papers:}

\section{References}

[1] R. K. Tatawat, P. Singh Chandel, “ Quality of ground water of Jaipur city, Rajasthan (India) and its suitability for domestic and irrigation purpose" Applied Ecology and Environmental Research 6(2),2007, 79-88.

[2] Izhar-ul-haq el at. , "Characterization of tube well irrigation water and associated soils in the salt affected area of district Mardan", Sarhad Journal of agric. vol. 23, no. 2, 2007.

[3] Abhay Kumar Singh, B. K. Tewary, A. Sinha, "Hydrochemistry and Quality Assessment of Groundwater in Part of NOIDA Metropolitan City, Uttar Pradesh", Journal Geological Society of India, vol.78, December,2011 pp.523-540.

[4] APHA Standard methods for the examination of water and wastewater (Washington, DC: American Public Health Association, 326, 1992).

[5] U S Salinity Laboratory Staff Diagnosis and improvement of saline and alkaline soils, USDA hand book 60(USDA, Washington, 1954).

[6] Saumitra Mukherjee, Bir Abhimanyu Kumar, László Körtvélyessy, “Assessment of groundwater quality in the south 24-parganas, west Bengal coast, india” Journal of Environmental Hydrology, Volume 13, July 2005 pp. 15.

[7] L. Belkhiri, A. Boudoukha and L. Mouni, "Groundwater quality and its suitability for drinking and agricultural use in Ain Azel plain, Algeria", Journal of Geography and Regional Planning Vol. 3(6) , June 2010, pp. 151-157.

[8] M. Amir Khattak el. at.,"Evaluation of ground water quality for irrigation and drinking purposes of the areas adjacent to Hudiara industrial drain, Lahore, Pakistan”, Pak. J. Agri. Sci., Vol. 49(4), 2012,549-556.

[9] Li Peiyue, Wu Qian, Wu Jianhua "'Groundwater Suitability for Drinking and Agricultural Usage in Yinchuan Area, China" International journal of Environmental sciences, Volume 1, No 6, 2011.

[10] Rajdeep Kaur and R.V. Singh, "Assessment for different groundwater quality parameters for irrigation purposes in Bikaner city, Rajasthan" Journal of applied sciences in environmental sanitation, 6 (3), 2011, 385-392.

[11] A.B. Narayanpethkar , A.S. Deshpande ,"Groundwater quality study of bhandarkav the village of Solapur district, Maharastra, India Journal of applied Hydrology, Vol. xxiv, no. 3 \& 4, July - Sept ,2011 pp. no. 37-46. 